
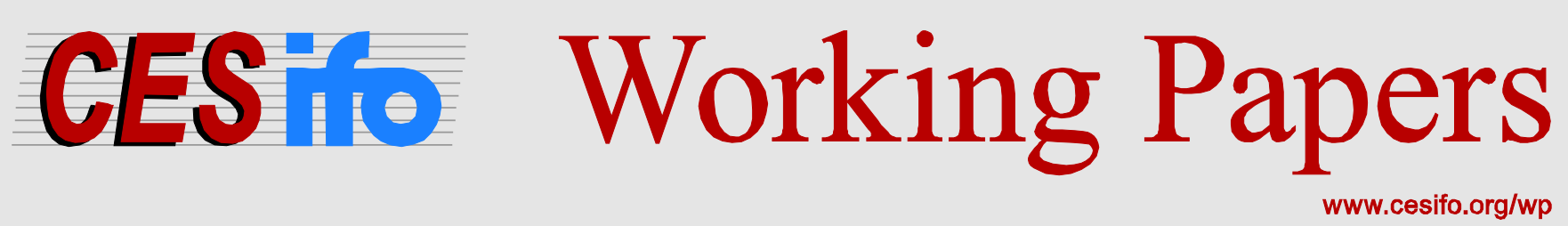

\title{
Union Bargaining Power and Product Innovation: Relevance of the Preference Function
}

\author{
Debasmita Basak \\ Andreas Hoefele \\ Arijit Mukherjee
}

CESIFO WORKING PAPER NO. 5007

CATEGORY 11: INDUSTRIAL ORGANISATION

OCTOBER 2014

An electronic version of the paper may be downloaded

- from the SSRN website:

- from the RePEc website:

- from the CESifo website:

WWW.SSRN.com

www.RePEc.org

www.CESifo-group.org/wp

\section{CESifo}




\title{
Union Bargaining Power and Product Innovation: Relevance of the Preference Function
}

\begin{abstract}
We show the effects of the bargaining power of labour unions on product innovation under decentralised and centralised wage bargaining. In this context, we show the implications of preference function, which affects the market size. A higher union bargaining power increases innovation if bargaining is decentralised, the market expansion effect is weak and the cost of innovation is moderate but low. Otherwise, a higher union bargaining power reduces innovation. Hence, whether a higher union bargaining power increases or decreases product innovation depends on the type of wage bargaining, market expansion effect and the cost of innovation.
\end{abstract}

JEL-Code: D430, J510, L130, O310.

Keywords: centralised union, decentralised union, product innovation, union utility.

Debasmita Basak* School of Accounting, Finance and Economics, School of Management Swansea University

United Kingdom - Swansea, SA1 5RS d.basak@swansea.ac.uk
Andreas Hoefele School of Business and Economics Loughborough University United Kingdom ahoefele@googlemail.com

\author{
Arijit Mukherjee \\ Nottingham University Business School \\ Nottingham / United Kingdom \\ arijit.mukherjee@nottingham.ac.uk
}

*corresponding author

We thank all seminar participants at Keele University, University of Nottingham, Loughborough University and the conference participants of SMYE, UECE, EARIE for helpful comments and particularly, Gamal Atallah and Gauthier Lanot for constructive suggestions. The usual disclaimer applies. 


\section{Introduction}

It is usually believed that higher bargaining power of the input supplier reduces the final goods producer's incentive for innovation. For example, considering labour union as the input supplier and using bargaining between a firm and a labour union, Grout (1984) shows that higher union bargaining power creates a negative impact on process innovation, which is due to the 'hold-up' problem created by the labour union. However, Ulph and Ulph (1989, 1994 and 1998) show that whether this hold-up problem remains in an oligopoly with strategic R\&D competition is not immediate and may depend on the type of bargaining. If the firms and the unions engage in an ex-post (short-term) bargaining, where bargaining does not occur on the R\&D investment, higher union bargaining power reduces $\mathrm{R} \& \mathrm{D}$ investment if bargaining is over wages alone, i.e., employing a right-to-manage model of labour union. However, if the bargaining takes place over wages and employment, i.e., there is efficient bargaining between firm and labour union, higher union bargaining power increases R\&D investment if the unions are relatively risk averse and the union is weak. If the firms and the unions enter into an ex-ante (long-term) bargaining so that bargaining occurs on the $\mathrm{R} \& \mathrm{D}$ investment, wage and employment, higher union bargaining power increases (decreases) R\&D investment if successful innovation increases (decreases) employment. ${ }^{1}$

The empirical evidence on labour union and innovation is also inconclusive. Freeman and Medoff (1984) show that the effect of unionisation is ambiguous on innovation. Hirsch (1992) shows that most U.S. studies show a negative effect between union power and innovation. Using COMPUSTAT data, Bronas and Deere (1993) show that there is a significant negative relationship between firm-specific unionisation rate and innovation. Using mainly aggregative industry level data, Ulph and Ulph (1989) find a negative relation for the high-tech industries in England, while Addison and Wagner (1994) find a positive but insignificant relation. It is documented in Menezes-Filho et al. (1998) that most U.S. studies show a negative effect between union power and innovation, while the evidence from some European studies is less compelling. Menezes-Filho and Van Reenen (2003) also show strong and negative effects of unions on innovation in North America, while that is generally not the case in the UK. Using Canadian data, Walsworth (2010) shows that the presence of union creates a small positive effect on product innovation.

While the existing theoretical literature provides important insights into the relation between labour union and process innovation, it ignores an important phenomenon of the contemporary world, viz., product innovation. Empirical evidence shows that firms spend significant amount on product innovation. For example, Japanese firms allocate $40 \%$ of their R\&D budget to product in-

\footnotetext{
${ }^{1}$ For an excellent survey of the literature see Menezes-Filho and Van Reenen (2003).
} 
novation (Imai, 1992). For a sample of US firms, Mansfield (1988) reports that on average the firms spent more on product innovation than Japanese firms. Pavitt et al. (1987) reports that $63 \%$ to $75 \%$ of innovations are product innovations in the $\mathrm{UK}^{2}$

We fill this gap in this paper by examining the relation between labour union and product innovation. Our analysis provides new insights. More specifically, considering ex-post bargaining and the right-to-manage ${ }^{3}$ unionfirm bargaining, we show that there may be a positive relation between union bargaining power and innovation, which is in contrast to the existing theoretical literature. ${ }^{4}$ In this respect, the consumer's preference affecting the market expansion effect (more on this later) following new product invention plays an important role.

It is intuitive that process and product innovations create different effects on labour demand and unionised wages. While product innovation directly increases the number of products in the market, thus creating additional demand for workers, process innovation increases productivities of the workers, thus creating an ambiguous effect on the demand for workers due to its expansionary effect on the output. In addition, product innovation may also affect the aggregate market size ${ }^{5}$ and may play an important role.

We adopt a framework similar to Ulph and Ulph (1994) with the exception that we consider product innovation where the firms invest to innovate new products. This framework will allow us to show the implications of product innovation and the consumer's preference function in the simplest way by contrasting our results with the existing literature showing a negative relation between union bargaining power and process innovation under ex-post bargaining and the right-to-manage model of labour unions.

We consider an economy with two quantity-setting firms competing with

\footnotetext{
${ }^{2}$ They highlight that there is heterogeneity between industries in the share spend on product innovation, where the share of product innovation is negatively correlated with firm size. They report that for large firms in the UK $63 \%$ of their innovation activity is in new products.

${ }^{3}$ See, Layard et al. (1991) for arguments in favour of the right-to-manage model.

${ }^{4}$ Since the right-to-manage model and ex-post bargaining, suggesting that bargaining occurs only on the input price, is also a reasonable situation to consider when the input supplier is not a labour union but it is an intermediate goods producer, it is immediate that if the weights on the input price and the quantity of inputs sold are the same, this result also suggests that higher bargaining power of the input supplier reduces the final goods producer's R\&D investment if the input supplier charges a linear price.

${ }^{5}$ Markets differ in their degree of saturation. For example, the market for cars seems more saturated than for mobile phones. The introduction of a new generation mobile phone may have a greater effect on the aggregate demand than the introduction of a car with a green technology.
} 
imperfect substitutes. Each firm can innovate a new product, which is added to the production line. Once the innovation decision is taken, the firm and the union bargain for wage. We consider two types of wage bargaining: decentralised or firm-specific union-firm bargaining and centralised or an industrywide union-firm bargaining. An important feature of our work is to show the implications of consumer's preference function affecting the market size. We consider an utility function that captures the well-known preference functions due to Bowley (1924) and Shubik and Levitan (1980). While the new products expand the market size under the former utility function, the market size does not depend on the number of products under the later utility function.

Our results suggest that whether a firm's incentive to innovate increases or decreases with the bargaining power of the union depends on the magnitude of the market expansion effect, the type of bargaining and the cost of innovation determining the number of firms undertaking innovation in equilibrium. Notably, a higher union bargaining power increases innovation if bargaining is decentralised, the market expansion effect is weak and the cost of innovation is moderate but low. Otherwise, a higher union bargaining power reduces innovation. ${ }^{6}$ Thus, we show that the relation between union power and product innovation may be either positive or negative, depending on the preference function, thus justifying the mixed empirical evidence. More specifically, the positive relation between union bargaining power and the incentive for product innovation shown in our paper provides an explanation for the empirical finding of Walsworth (2010) showing that the presence of union creates a small positive effect on product innovation.

Our paper contributes to the literature in several ways. First, as already mentioned, in contrast to the existing literature, we consider the effects of new product innovation. Second, we analyse the implications of the union bargaining power on innovation under centralised bargaining, which has not been studied in the existing literature. Finally, our paper shows the role of the market expansion effect for the union-innovation nexus, which has been overlooked in the existing literature.

The rest of the paper is organised as follows. Section 2 describes the model. Section 3 and 4 analyse the cases of decentralised and centralised bargaining respectively. Section 5 concludes.

\footnotetext{
${ }^{6}$ Although we consider labour union as the upstream agent, it is worth mentioning that our results will hold if, instead of labour unions, we consider the upstream agents as profit maximising input suppliers. With this interpretation, decentralised bargaining corresponds to a situation where firm-specific input suppliers bargain with respective firms, and the centralised bargaining corresponds to a situation where a representative of the input suppliers bargains with a representative of the final goods producers.
} 


\section{The model}

We consider an economy with two firms, indexed by $k=1,2$. Initially each firm produces a single good, $g$ and $h$ respectively. The goods are assumed to be horizontally differentiated. Each firm can innovate a new product by investing $I>0$. We denote the new products by $x$ and $y$ produced by firm 1 and firm 2 respectively. If a firm innovates, it becomes a multiproduct firm. Our R\&D process follows the recent works of Calabuig and GonzalezMaestre (2002), Haucap and Wey (2004) and Mukherjee and Pennings (2011) with the exception that, instead of considering lower cost of production of the existing products, we consider developments of new products. Our modelling of product innovation is in line with Mukherjee and Sinha (2013).

We assume that the firms use labour $L_{i}$ as the sole input to produce each good $i=g, h, x, y$. Furthermore, we assume for simplicity that one unit of output of each good requires one unit of labour. The total labour demand per firm is $L_{k}=\sum L_{i}$. As alluded in the introduction, the firms hire workers from unions. We consider two types of bargaining: decentralised bargaining and centralised bargaining. We assume that the equilibrium wages are determined by generalised Nash bargaining between the firms and the unions.

The timing of the game is as follows. At stage one, the firms decide simultaneously whether or not to innovate a new product which is an imperfect substitute of the existing product. At stage two, the equilibrium wages are determined. At stage three, the firms determine their outputs simultaneously and the profits are realised. We solve the game through backward induction.

\subsection{Preference function}

On the demand side, we assume that a representative consumer's utility is

$$
U=a \sum_{i} q_{i}-(1+\sigma(n-1)(1-\gamma)) \frac{1}{2} \sum_{i} q_{i}^{2}-\gamma \sum_{i, i \neq j} q_{i} q_{j}+\xi
$$

where $\xi$ is the numeraire good and $q_{i}$ is the output of good $i$. The number of goods produced and consumed is $n \in\{2,3,4\}$. The parameter $\gamma \in[0,1)$ shows the degree of product differentiation. If $\gamma=0$, the goods are isolated and if $\gamma=1$, the goods are perfect substitutes. Because we consider the new products $x$ and $y$ to be different from the existing products $g$ and $h$, we ignore the case of $\gamma=1$. The parameter $\sigma \in[0,1]$ measures the degree of market expansion, where the upper boundary, $\sigma=1$, corresponds to no market expansion effect, as in Shubik and Levitan (1980) and the lower boundary, $\sigma=0$, corresponds to full market expansion effect, as in Bowley (1924).

The resulting inverse demand function for $\operatorname{good} i$ is:

$$
p_{i}=a-\alpha q_{i}-\gamma \sum_{j} q_{j},
$$


where $\alpha \equiv 1+\sigma(n-1)(1-\gamma)$.

To provide a better understanding of the market expansion effect, we aggregate the demand functions, which yields:

$$
Q=[1+(n-1) \gamma+\sigma(n-1)(1-\gamma)]^{-1} n[a-\bar{P}]
$$

where $\bar{P}=\frac{1}{n} \sum_{i} p_{i}$ denotes the average price. Like a standard demand function, the aggregate demand is decreasing in the average price. Additionally, for $\sigma \in[0,1)$, the aggregate demand is increasing in the number of varieties, but it is independent of the number of goods and the degree of product differentiation for $\sigma=1$. This implies that the introduction of new products does not change the market size for $\sigma=1$.

\subsection{The output game}

We start by considering the output game. At this stage, the firms take the number of products and the wage as given. Each firm maximises its profit by setting the output of each of its products. We determine the outputs for all possible cases of innovation: neither firm innovates, either firm 1 or firm 2 innovates and both firms innovate.

If neither firm innovates the equilibrium outputs are

$$
\begin{aligned}
& q_{g}=\frac{a(2 \alpha-\gamma)-2 \alpha w_{1}+\gamma w_{2}}{4 \alpha^{2}-\gamma^{2}} \\
& q_{h}=\frac{a(2 \alpha-\gamma)+\gamma w_{1}-2 \alpha w_{2}}{4 \alpha^{2}-\gamma^{2}} .
\end{aligned}
$$

If firm 1 innovates a new product but firm 2 does not innovate, the equilibrium outputs are

$$
\begin{aligned}
& q_{g}=q_{x}=\frac{a(2 \alpha-\gamma)-2 \alpha w_{1}+\gamma w_{2}}{2\left(2 \alpha^{2}+2 \alpha \gamma-\gamma^{2}\right)} \\
& q_{h}=\frac{a \alpha+\gamma w_{1}-(\alpha+\gamma) w_{2}}{\left(2 \alpha^{2}+2 \alpha \gamma-\gamma^{2}\right)} .
\end{aligned}
$$

If firm 2 innovates a new product and firm 1 chooses not to innovate, the equilibrium outputs are

$$
\begin{aligned}
& q_{g}=\frac{a \alpha+\gamma w_{1}-(\alpha+\gamma) w_{2}}{\left(2 \alpha^{2}+2 \alpha \gamma-\gamma^{2}\right)} \\
& q_{h}=q_{y}=\frac{a(2 \alpha-\gamma)-2 \alpha w_{1}+\gamma w_{2}}{2\left(2 \alpha^{2}+2 \alpha \gamma-\gamma^{2}\right)} .
\end{aligned}
$$


If both firms innovate new products, the equilibrium outputs are

$$
\begin{aligned}
& q_{g}=q_{x}=\frac{a \alpha-(\alpha+\gamma) w_{1}+\gamma w_{2}}{2 \alpha(\alpha+2 \gamma)} \\
& q_{h}=q_{y}=\frac{a \alpha+\gamma w_{1}-(\alpha+\gamma) w_{2}}{2 \alpha(\alpha+2 \gamma)} .
\end{aligned}
$$

The specific expressions for the equilibrium outputs under no market expansion effect $(\sigma=1)$ and full market expansion effect $(\sigma=0)$ are reported in Appendix A.

Next, we will discuss the wage setting game. As discussed before, there is either decentralised bargaining or centralised bargaining. We will begin our analysis with decentralised bargaining and investigate the firms' innovation incentives under the two types of market structures. In the subsequent section, we will repeat the same exercise under a centralised bargaining.

\section{Decentralised Wage bargaining}

Having derived the equilibrium outputs in Section 2.2, we now determine wage under decentralised bargaining. We assume that the utility of the $k^{\text {th }}$ firmspecific union, $k=1,2$, is $U_{k}=\left(w_{k}-c\right) L_{k}$ where $c(0<c<1)$ is the reservation wages of the workers. The wage, $w_{k}$, paid by the $k^{\text {th }}$ firm is determined by maximizing the following generalised Nash bargaining expression

$$
\left(U_{k}-\widetilde{U}\right)^{\beta}\left(\pi_{k}-\tilde{\pi}\right)^{1-\beta}
$$

where $\widetilde{U}$ and $\widetilde{\pi}$ are the disagreement pay-offs of the unions and the firms respectively. Following the papers mentioned in the introduction, we consider closed-shop unions (meaning that all the workers are the members of unions), suggesting that, in the event of a strike, the firms stop producing. Hence, the reservation utilities of the unions and the firms are zero. The parameter $\beta$ (respectively $1-\beta$ ) measures the bargaining power of the unions (respectively firms). A higher value of $\beta$ corresponds to a higher bargaining power of the unions. At the extreme, if $\beta=1$, the unions have full bargaining power, and if $\beta=0$, the firms have full bargaining power. The latter case is similar to the situation with no labour union. We restrict our analysis to $\beta \in(0,1)$.

We determine the wages for the four cases of innovation: neither firm innovates, only one firm innovates and both firms innovate. If neither firm innovates, the equilibrium wages are

$$
\widehat{w}_{1}^{d}=\widehat{w}_{2}^{d}=\frac{a \beta(2 \alpha-\gamma)+2 c \alpha(2-\beta)}{4 \alpha-\beta \gamma} .
$$


Next, we consider the case where only one firm innovates. For notational ease, we denote the innovating firm by ' $i v$ ' and the non-innovating firm by ' $n v$ '. In this case, the equilibrium wages are

$$
\begin{aligned}
w_{i v}^{d} & =\frac{a \beta\left(4 \alpha^{2}+2 \alpha \gamma+\alpha \beta \gamma-2 \gamma^{2}\right)+c(2-\beta)(\alpha+\gamma)(4 \alpha+\beta \gamma)}{\left(8 \alpha^{2}+8 \alpha \gamma-\beta^{2} \gamma^{2}\right)} \\
w_{n v}^{d} & =\frac{a \beta\left(4 \alpha^{2}+2 \alpha \beta \gamma-\beta \gamma^{2}\right)+2 c \alpha(2-\beta)(2 \alpha+2 \gamma+\beta \gamma)}{\left(8 \alpha^{2}+8 \alpha \gamma-\beta^{2} \gamma^{2}\right)} .
\end{aligned}
$$

Finally, if both the firms innovate, the equilibrium wages are

$$
\bar{w}_{1}^{d}=\bar{w}_{2}^{d}=\frac{a \alpha \beta+c(2-\beta)(\alpha+\gamma)}{2 \alpha+2 \gamma-\beta \gamma} .
$$

The respective wages under no market expansion effect $(\sigma=1)$ and full market expansion effect $(\sigma=0)$ are enumerated in Appendices (B.1a) and (B.2a).

\subsection{Demand function with no market expansion effect}

In this subsection we determine the equilibrium at the innovation stage, which allows us to study the effects of the union bargaining power on innovation. We start the analysis by considering the case of no market expansion effect $(\sigma=1)$, which corresponds to the demand function in Shubik and Levitan (1980).

We first focus on the wage effects.

Lemma 1 If wages are determined through decentralised bargaining and if there is no market expansion effect $(\sigma=1)$, wages react to innovation as follows:

(a) If only one firm innovates, the innovating firm pays a higher wage under innovation compared to no innovation, $\left(w_{i v}^{d}-\widehat{w}_{k}^{d}>0\right)$.

(b) If both firms innovate, the innovating firms pay the same wage under innovation and no innovation, $\left(\bar{w}_{k}^{d}-\widehat{w}_{k}^{d}=0\right)$.

Proof. See Appendix (B.1b).

If only one firm innovates, there are two effects on the labour demand curve. First, the labour demand schedule of the innovating firm shifts out. The reason is that, although the aggregate market does not increase, market shares are shifted towards the innovating firm, at the expense of the noninnovating firm. Second, the labour demand curve becomes steeper in response to the firm innovating. This effect implies that the new equilibrium in the wage bargaining stage of the game is at the less elastic part of the labour 
demand curve, allowing the union to set a higher wage. Hence, in the case under consideration, the innovating firm pays a higher wage under innovation compared to no innovation.

If both firms innovate, they share the market equally, with total output being the same as in the case of no-innovation. This means that the two labour demand schedules coincide, leading to the same wage under innovation and no-innovation. ${ }^{7}$

We now analyse the first stage of the game, in which the firms decide on their innovation efforts. Let $\pi_{k}^{d}[.,$.$] denote the profit of the k^{\text {th }}$ firm under decentralised bargaining where the first (second) argument indicates the goods produced by firm $1(2)$. For example, $\pi_{k}^{d}[(g, x), h]$ indicates the profit of firm $k$ when firm 1 innovates and produces two goods, $x$ and $g$, and firm 2 does not innovate and produces $h$ only. Table 1 summarises the possible strategies of each firm and the realised profits. ${ }^{8}$

Table 1

\begin{tabular}{c|c|c}
\hline $\begin{array}{c}\text { Firm } 2 \rightarrow \\
\text { Firm 1 }\end{array}$ & R\&D & No R\&D \\
\hline & & \\
R\&D & $\pi_{1}^{d}[(g, x) ;(h, y)]-I$, & $\pi_{1}^{d}[(g, x) ; h]-I$, \\
& $\pi_{2}^{d}[(g, x) ;(h, y)]-I$ & $\pi_{2}^{d}[(g, x) ; h]$ \\
No R\&D & $\pi_{1}^{d}[g ;(h, y)]$, & $\pi_{1}^{d}[g ; h]$, \\
& $\pi_{2}^{d}[g ;(h, y)]-I$ & $\pi_{2}^{d}[g ; h]$ \\
\hline
\end{tabular}

From table 1, we can derive the Nash equilibria of the innovation game for different investment costs. The incentive for a firm to innovate, given the strategy of the competitor, is the change in profits from innovation and no innovation. A firm will innovate if the additional profit from innovation exceeds the innovation cost. In the following lemma, we define the investment costs at which a firm is indifferent between innovating or not, given the innovation decision of the rival. For all investment costs below this critical investment cost, a firm's willingness to pay for the innovation exceeds the actual investment cost and therefore, the firm will choose to innovate. Accordingly, which Nash equilibrium is achieved depends on the size of the investment cost, $I$.

Lemma 2 If there is no market expansion effect $(\sigma=1)$, the following investment rankings hold true under decentralised bargaining:

\footnotetext{
${ }^{7}$ Using the appropriate values for $\sigma$, i.e., considering $\alpha=2-\gamma$ under no innovation and $\alpha=4-3 \gamma$ under innovation by both firms, we get that the total labour demand faced by the $k^{\text {th }}$ union is $\frac{a(4-3 \gamma)-2(2-\gamma) w_{1}+\gamma w_{2}}{(4-\gamma)(4-3 \gamma)}$ for no innovation and innovation by both firms.

${ }^{8}$ The equilibrium profits of the firms are documented in Appendix B.1c.
} 
(a) Both firms innovate if $I<I_{l}^{d}$,

(b) Only one firm innovates if $I_{l}^{d}<I<I_{h}^{d}$,

(c) Neither firm innovates if $I_{h}^{d}<I$,

$$
\begin{aligned}
& \text { where } I_{l}^{d} \equiv(2-\gamma)^{3}\left(\frac{2(a-c)(2-\beta)}{(4-\gamma)(8-4 \gamma-\beta \gamma)}\right)^{2}-(3-2 \gamma)\left(\frac{(a-c)(2-\beta)(3-\gamma)\left(36-48 \gamma+6 \beta \gamma+16 \gamma^{2}-5 \beta \gamma^{2}\right)}{3\left(6-6 \gamma+\gamma^{2}\right)\left(72-72 \gamma+16 \gamma^{2}-\beta^{2} \gamma^{2}\right)}\right)^{2} \\
& \text { and } I_{h}^{d} \equiv 2(3-\gamma)\left(\frac{(a-c)(2-\beta)(3-2 \gamma)\left(36-42 \gamma+3 \beta \gamma+10 \gamma^{2}-2 \beta \gamma^{2}\right)}{3\left(6-6 \gamma+\gamma^{2}\right)\left(72-72 \gamma+16 \gamma^{2}-\beta^{2} \gamma^{2}\right)}\right)^{2}-(2-\gamma)^{3}\left(\frac{2(a-c)(2-\beta)}{(4-\gamma)(8-4 \gamma-\beta \gamma)}\right)^{2}
\end{aligned}
$$

Proof. See Appendix (B.1d).

We can describe the equilibrium R\&D strategy of the firms in terms of non-strategic and strategic benefits from innovation (Roy Chowdhury, 2005). A firm's non-strategic (strategic) benefit from innovation is given by its payoff from innovation, net of its payoff from no innovation, when the rival does not innovate (innovates). ${ }^{9}$

The implication of lemma 2 is that the non-strategic benefit from innovation is higher than the strategic benefit from innovation. If the rival innovates a new product, the market becomes competitive, reducing the profits and therefore innovation. Hence, if firm 2 does not innovate, firm 1 innovates if its gross non-strategic benefit from innovation is greater than the cost of innovation, which happens for $I<I_{h}^{d}$. If firm 2 innovates, it reduces firm 1's gross benefit from innovation. However, even if firm 2 innovates, firm 1's gross benefit from innovation is higher than the cost of innovation if $I<I_{l}^{d}$. Hence, if firm 2 innovates, firm 1 innovates for $I<I_{l}^{d} \cdot{ }^{10}$

Proposition 1 If there is no market expansion effect $(\sigma=1)$, an increase in union bargaining power under decentralised bargaining yields

(a) an increase in the incentive for product innovation by increasing the range of the cost of innovation for which both firms innovate in equilibrium, $\frac{\partial I_{l}^{d}}{\partial \beta}>0$,

(b) a decrease in the incentive for innovation by increasing the range of the cost of innovation for which neither firm innovates in equilibrium, $\frac{\partial I_{h}^{d}}{\partial \beta}<$ 0 .

\footnotetext{
${ }^{9}$ In the line with Ulph and Ulph (1998), the critical values $I_{l}^{d}$ and $I_{h}^{d}$ represent competitive threats, which is the difference between a firm's profits if it innovates and the profits if it does not innovate, given the strategy by its rival firm.

${ }^{10}$ Since the firms are symmetric, the decision of firm 2 to innovate is analogous.
} 
Proof. See Appendix (B.1e).

Proposition 1(a) is in contrast to the existing literature with process innovation (see, e.g., Ulph and Ulph, 1989, 1994 and 1998) showing that a higher union bargaining power reduces the incentive for innovation. Thus, our result shows that the relation between union bargaining power and the incentive for process innovation may not hold true in the case of product innovations.

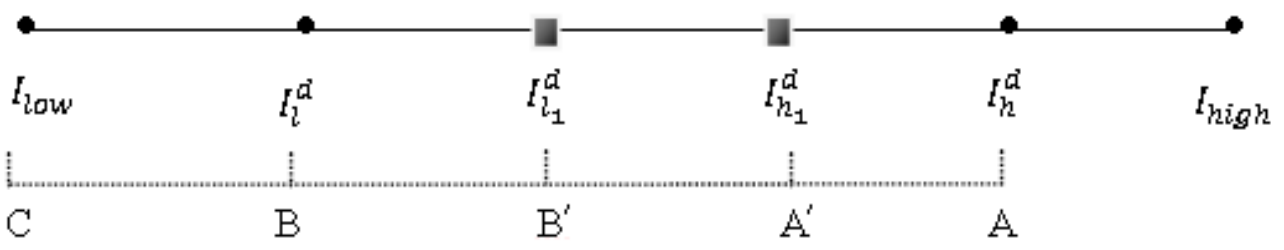

Figure 1

We illustrate the above proposition in Figure 1 where we draw an investment scale and depict the critical investment levels $I_{l}^{d}$ and $I_{h}^{d}$ for a given bargaining power of the unions. Hence, for a given bargaining power of the unions, the distance $C B$ shows the region where both firms innovate, the distance $B A$ shows the region where only one firm innovates and the region beyond point $A$ shows where neither firm innovates. With an increased bargaining power of the unions, the critical investment levels move to $I_{l_{1}}^{d}\left(>I_{l}^{d}\right)$ and $I_{h_{1}}^{d}\left(<I_{h}^{d}\right)$. Hence, under a higher bargaining power of the unions, the distance $C B^{\prime}$ shows the region where both firms innovate, the distance $B^{\prime} A^{\prime}$ shows the region where only one firm innovates and the region beyond point $A^{\prime}$ shows where neither firm innovates. The comparison between these regions reveals that higher bargaining power of the unions increases the possibility of innovation by both firms (shown by the region $B B^{\prime}$ ) and innovation by neither firm (shown by the region $A^{\prime} A$ ), thus showing a positive (negative) relation between union bargaining power and the incentive for innovation for moderate but low (high) cost of innovation.

On one hand, a higher union power helps the unions to extract more rents from the firms ex-post innovation, which tends to reduce the firms' benefits from innovation and therefore, tends to reduce the incentive for innovation. On the other hand, the profit loss under no innovation due to a higher union power tends to increase the firms' gains from innovation. Our results under no market expansion effect show that whether the innovation reducing effect dominates or dominated by the innovation raising effect depends on the number of firms undertaking innovation in equilibrium. In other words, whether the 
innovation reducing effect dominates or dominated by the innovation raising effect depends on the strategic and non-strategic incentives for innovation.

In this subsection, we have derived our results for the case of no market expansion effect. However, it is immediate that since the equilibrium values are continuous in the market expansion term, $\sigma$, our results of this section hold even if there is positive but weak market expansion effect.

\subsection{Demand function with full market expansion effect}

Next, we analyse the case of a full market expansion effect, where $\sigma=0$. This case is similar to the demand function in Bowley (1924).

Lemma 3 If the wages are determined through decentralised bargaining and the market expansion effect is full $(\sigma=0)$, wages react to innovation as follows:

(a) Compared to the case with no innovation, innovation reduces the wage paid by the innovating firm if both firms innovate, $\left(\bar{w}_{k}^{d}-\widehat{w}_{k}^{d}<0\right)$, or only one firm innovates, $\left(w_{i v}^{d}-\widehat{w}_{k}^{d}<0\right)$.

(b) The fall in the wage of the innovating firm is higher when both firms innovate compared to the case where only one firm innovates.

Proof. See Appendix (B.2b).

Lemma 3 shows how wages vary with firms' innovation decisions. The lemma states that innovation makes the innovating firm more cost efficient by lowering wages paid to the union. In general, innovation (compared to no innovation) increases the labour demand of the innovating firm. As unions care about employment and wages, the outward shift of the labour demand curve leads to a new equilibrium at the more elastic part of the labour demand curve, which results in a reduction of the equilibrium wage paid by the innovating firm.

The second part of the lemma states that the downward pressures on the wages are stronger when both firms innovate. The reason is that with both firms introducing new varieties to the market, the aggregate demand increases more, shifting the labour demand curve further out. The new equilibrium in the wage setting is in an even less elastic part of the labour demand curve, resulting in a lower wage.

Analogous to the case of no market expansion effect, we now derive the investment decisions made by the firms. The equilibrium profits are documented in Appendix B.2c.

Lemma 4 If there is full market expansion effect $(\sigma=0)$ the following investment ranking is true under decentralised bargaining: 
(a) Both firms innovate if $I<I_{l}^{d}$

(b) Only one firm innovates if $I_{l}^{d}<I<I_{h}^{d}$

(c) Neither firm innovates if $I_{h}^{d}<I$

$$
\begin{aligned}
& \text { where } I_{l}^{d}=\frac{1}{2}(a-c)^{2}(2-\beta)^{2}(1+\gamma)^{2}\left(\frac{1+\gamma}{(1+2 \gamma)^{2}(2+2 \gamma-\beta \gamma)^{2}}-\frac{2\left(4+2 \beta \gamma-\beta \gamma^{2}\right)^{2}}{\left(2+2 \gamma-\gamma^{2}\right)^{2}\left(8+8 \gamma-8 \beta^{2} \gamma^{2}\right)^{2}}\right) \\
& \text { and } I_{h}^{d}=2(a-c)^{2}(2-\beta)^{2}\left(\frac{(1+\gamma)\left(4+2 \gamma+\beta \gamma-2 \gamma^{2}\right)^{2}}{\left(2+2 \gamma-\gamma^{2}\right)^{2}\left(8+8 \gamma-8 \beta^{2} \gamma^{2}\right)^{2}}-\frac{2}{(2+\gamma)^{2}(4-\beta \gamma)^{2}}\right) .
\end{aligned}
$$

Proof. See Appendix (B.2d)

The lemma states that the non-strategic benefit from innovation is higher than the strategic benefit from innovation. The intuition is similar to Lemma 2 .

We now investigate how bargaining power of the union affects the innovation incentive of a firm.

Proposition 2 If there is full market expansion effect $(\sigma=0)$, an increase in the union bargaining power under decentralised bargaining reduces the incentive for product innovation, i.e. $\frac{\partial I_{l}^{d}}{\partial \beta}<0$ and $\frac{\partial I_{h}^{d}}{\partial \beta}<0$.

Proof. See Appendix (B.2e).

Analogous to Proposition 1, we illustrate Proposition 2 with the help of Figure 2 where we draw an investment scale and depict the critical investment levels $I_{l}^{d}$ and $I_{h}^{d}$ for a given bargaining power of the unions. Hence, for a given bargaining power of the unions, the distance $G F$ shows the region where both firms innovate, the distance $E F$ shows the region where only one firm innovates and the region above point $E$ shows where neither firm innovates. With an increased bargaining power of the unions, the critical investment levels move to $I_{l_{2}}^{d}\left(<I_{l}^{d}\right)$ and $I_{h_{2}}^{d}\left(<I_{h}^{d}\right)$. Hence, under a higher bargaining power of the unions, the distance $G F^{\prime}$ shows the region where both firms innovate, the distance $F^{\prime} E^{\prime}$ shows the region where only one firm innovates and the region above point $E^{\prime}$ shows where neither firm innovates. The comparison between these regions reveals that a higher bargaining power of the unions reduces the possibility of innovation by both firms (shown by the region $F^{\prime} F$ ) and increases the possibility of innovation by neither firm (shown by the region $E^{\prime} E$ ), thus showing a negative relation between union bargaining power and the incentive for innovation. 


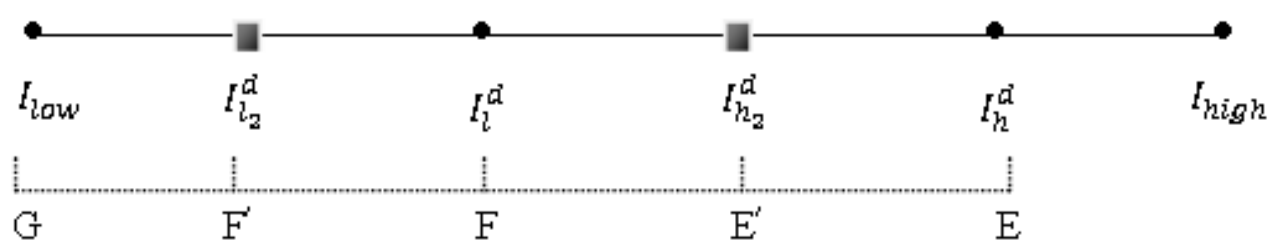

Figure 2

The above proposition confirms the results of the existing literature with process innovation (see, e.g., Ulph and Ulph, 1989, 1994 and 1998), where an increase in union bargaining power reduces the incentive for innovation. Both the innovation raising and innovation reducing effects, as mentioned under the case of no market expansion effect, remain in the case of full market expansion effect. Our results under full market expansion effect show that the profit loss under innovation dominates that of under no innovation, thus reducing the incentive for innovation following an increase in union bargaining power.

\section{Centralised wage bargaining}

Like the existing literature (Ulph and Ulph, 1989, 1994 and 1998 and MenezesFilho et al., 1998 and 2003), we have so far considered the case of a decentralised bargaining where the firms bargain with firm-specific unions. However, centralised bargaining, where a representative of the industry bargains with a representative of the union, is an alternative form of wage bargaining that has been considered in different contexts (Bughin and Vannini, 1995, Vannini and Bughin, 2000, Dhillon and Petrakis, 2002 and Mukherjee, 2007). The purpose of this section is to investigate the effects of an increase in union bargaining power on the incentive for innovation under a centralised bargaining, thus showing the effects of different bargaining structures.

The equilibrium outputs, and therefore the equilibrium labour demands, under a centralised bargaining are given by (4)-(11) with the wages as $w_{1}$ and $w_{2}$ under a discriminatory wage setting and with the wages as $w_{1}=w_{2}=w$ under a uniform wage setting.

Under a centralised bargaining, the industry-wide union's objective function is $U=\sum\left(w_{k}-c\right) L_{k}$ under a discriminatory wage setting and its objective function is $U=(w-c) \sum L_{k}$ under a uniform ware setting. Analogous to decentralised bargaining, the equilibrium wage is determined through Nash bargaining. Due to zero payoffs of the firms and the unions under no agreement, the wage under a centralised bargaining is determined by maximizing 
the following generalized Nash bargaining expression:

$$
U^{\beta}\left(\sum_{k=1}^{2} \pi_{k}\right)^{1-\beta}
$$

A centralised bargaining between the firms and the unions results in the equilibrium wages as $w^{c}=\frac{1}{2}(a \beta+2 c-c \beta)$ under both uniform and discriminatory wages and irrespective of the innovation strategies of the firms determining the number of products to be produced. The rationale for this result comes from Dhillon and Petrakis (2000), which suggests that, if the firm's equilibrium outputs and profits are log-linear in wage and the market features such as the number of firms and product differentiation, the equilibrium wages under a centralised bargaining remain the same irrespective of the number of firms innovating, the degree of product differentiation and the intensity of product-market competition.

Analogous to the previous section, we consider two polar cases: no market expansion effect and full market expansion effect. The respective payoffs of the firms are reported in Appendices (C.1a) and (C.2a).

\subsection{Comparison}

To keep our analysis simple and brief, we combine the cases of no and full market expansion effects together. The equilibrium profits, and the critical levels of R\&D investments mentioned in the following Lemma are shown in Appendix $C$ for the respective cases.

Lemma 5 If the wages are negotiated through centralised bargaining, regardless of the strength of the market expansion effect, the innovation decisions are given as follows:

(a) Both firms innovate if $I<I_{l}^{c}$

(b) Only one firm innovates if $I_{l}^{c}<I<I_{h}^{c}$

(c) Neither firm innovates if $I_{h}^{c}<I$.

Proof. See Appendices (C.1b) and (C.2b).

The above Lemma shows that the strategic incentive for innovation is lower than the non-strategic incentive for innovation. The intuition for Lemma 5 is analogous to that of Lemmas 2 and 4.

Now we show the effects of a higher union bargaining power on the incentive for innovation. 
Proposition 3 An increase in the bargaining power of the union under a centralised bargaining reduces the incentive for product innovation, i.e. $\frac{\partial I_{l}^{c}}{\partial \beta}<0$ and $\frac{\partial I_{h}^{c}}{\partial \beta}<0$, irrespective of the extent of market expansion effect.

Proof. See Appendix (C.1c) and (C.2c).

Like decentralised bargaining, a higher bargaining power of the union under a centralised bargaining reduces the profits of the firms, irrespective of the innovation decisions. Hence, both the innovation-raising and the innovationreducing effects of a higher union bargaining power remain under centralised bargaining. Our results show that the loss of profits under no innovation are lower compared to innovation by either one firm or by both firms, thus reducing the incentive for innovation.

\section{Conclusion}

The effects of labour unions on innovation has generated a considerable interest. While the existing literature has provided several important insights on this issue, the focus so far has been on process innovation only. However, evidence suggests that a large share of investment in innovation is in product innovation. By considering the role of product innovation in the unioninnovation nexus, this paper is a step to fill this gap.

The analyses in this paper suggests that there exist conditions under which an increase in the union bargaining power has a positive effect on innovation. In particular, a higher union bargaining power increases innovation if the wage bargaining is decentralised, the market expansion effect is weak and the cost of innovation is moderate but low. Otherwise, a higher union bargaining power reduces innovation. Hence, whether a higher union bargaining power increases or decreases product innovation depends on the type of wage bargaining, market expansion effect and the cost of innovation.

The role of market expansion is important for our analysis. One possible reason for different market expansion is the products' different positions at the product life cycle. Market expansions may be less in relatively matured industries. For example, the industry with desktop computers may be more matured than tablet computers. Hence, new product developments in the desktop computer industry may create relatively lower market expansion effect compared to the new product development in the tablet computer industry. With this interpretation, our results suggest that a higher union barging power would reduce innovation in industries which are at the earlier stages of the product life cycle with large market expansion possibility, whereas a higher union power might increase innovation in matured industries with lower market expansion possibility. 
While the existing literature focused on process innovation, this paper focused on product innovation. However, firms often invest in both product and process innovations. Hence, an interesting subject for further analysis would be to consider the effects of different union power when firms invest in both product and process innovations. In this respect, it would be interesting to see whether the effects of different types of innovations are substitutes or complements. We leave this for future research.

\section{Appendix A: Equilibrium output levels}

\begin{tabular}{c|c|c} 
& No market expansion effect & Full market expansion effect \\
\hline $\begin{array}{c}\text { Neither firm } \\
\text { innovates }\end{array}$ & $q_{g}=\frac{a(4-3 \gamma)-2(2-\gamma) w_{1}+\gamma w_{2}}{(4-\gamma)(4-3 \gamma)}$ & $q_{g}=\frac{a(2-\gamma)-2 w_{1}+\gamma w_{2}}{4-\gamma^{2}}$ \\
& $q_{h}=\frac{a(4-3 \gamma)+\gamma w_{1}-2(2-\gamma) w_{2}}{(4-\gamma)(4-3 \gamma)}$ & $q_{h}=\frac{a(2-\gamma)+\gamma w_{1}-2 w_{2}}{4-\gamma^{2}}$ \\
Firm 1 & $q_{g}=q_{x}=\frac{a(6-5 \gamma)-2(3-2 \gamma) w_{1}+\gamma w_{2}}{6\left(6-6 \gamma+\gamma^{2}\right)}$ & $q_{g}=q_{x}=\frac{a(2-\gamma)-2 w_{1}+\gamma w_{2}}{2\left(2+2 \gamma-\gamma^{2}\right)}$ \\
innovates & $q_{h}=\frac{a(3-2 \gamma)+\gamma w_{1}-(3-\gamma) w_{2}}{3\left(6-6 \gamma+\gamma^{2}\right)}$ & $q_{h}=\frac{a+\gamma w_{1}-(1+\gamma) w_{2}}{2+2 \gamma-\gamma^{2}}$ \\
Firm 2 & $q_{g}=\frac{a(3-2 \gamma)+\gamma w_{1}-(3-\gamma) w_{2}}{3\left(6-6 \gamma+\gamma^{2}\right)}$ & $q_{g}=\frac{a+\gamma w_{1}-(1+\gamma) w_{2}}{2+2 \gamma-\gamma^{2}}$ \\
innovates & $q_{h}=q_{y}=\frac{a(6-5 \gamma)-2(3-2 \gamma) w_{1}+\gamma w_{2}}{6\left(6-6 \gamma+\gamma^{2}\right)}$ & $q_{h}=q_{y}=\frac{a(2-\gamma)-2 w_{1}+\gamma w_{2}}{2\left(2+2 \gamma-\gamma^{2}\right)}$ \\
Both firms & $q_{g}=q_{x}=\frac{a(4-3 \gamma)-2(2-\gamma) w_{1}+\gamma w_{2}}{2(4-\gamma)(4-3 \gamma)}$ & $q_{g}=q_{x}=\frac{a-(1+\gamma) w_{1}+\gamma w_{2}}{2(1+2 \gamma)}$ \\
innovate & $q_{h}=q_{y}=\frac{a(4-3 \gamma)+\gamma w_{1}-2(2-\gamma) w_{2}}{2(4-\gamma)(4-3 \gamma)}$ & $q_{h}=q_{y}=\frac{a+\gamma w_{1}-(1+\gamma) w_{2}}{2(1+2 \gamma)}$ \\
\hline
\end{tabular}

\section{Appendix B: The case of Decentralised Unions}

\section{(B.1) The case of no market expansion effect}

(B.1a) The equilibrium wage rates:

\begin{tabular}{c|c} 
Weither firm & Wage rates \\
Innovates & $\widehat{w}_{1}^{d}=\widehat{w}_{2}^{d}=\frac{a \beta(4-3 \gamma)+2 c(2-\beta)(2-\gamma)}{8-4 \gamma-\beta \gamma}$ \\
One firm & $w_{i v}=\frac{a \beta\left(36-42 \gamma+3 \beta \gamma+10 \gamma^{2}-2 \beta \gamma^{2}\right)+c(2-\beta)(3-\gamma)(12-8 \gamma+\beta \gamma)}{72-72 \gamma+16 \gamma^{2}-\beta^{2} \gamma^{2}}$ \\
innovates & $w_{n v}=\frac{a \beta\left(36-48 \gamma+6 \beta \gamma+16 \gamma^{2}-5 \beta \gamma^{2}\right)+2 c(2-\beta)(3-2 \gamma)(6-2 \gamma+\beta \gamma)}{72-72 \gamma+16 \gamma^{2}-\beta^{2} \gamma^{2}}$ \\
$\begin{array}{c}\text { Both firms } \\
\text { innovate }\end{array}$ & $\bar{w}_{1}^{d}=\bar{w}_{2}^{d}=\frac{a \beta(4-3 \gamma)+2 c(2-\beta)(2-\gamma)}{8-4 \gamma-\beta \gamma}$ \\
\hline
\end{tabular}


(B.1b) Proof of Lemma 1

$$
w_{i v}-\widehat{w}_{k}^{d}=\frac{\beta \gamma(a-c)(2-\beta)(1-\gamma)(12-4 \gamma-\beta \gamma)}{(8-4 \gamma-\beta \gamma)\left(72-72 \gamma+16 \gamma^{2}-\beta^{2} \gamma^{2}\right)}>0 .
$$

\section{(B.1c) Firms' pay-off table}

\begin{tabular}{c|c} 
& Equilibrium profit levels \\
\hline $\begin{array}{c}\text { Neither firm } \\
\text { innovates }\end{array}$ & $\widehat{\pi}_{1}^{d}=\widehat{\pi}_{2}^{d}=(2-\gamma)^{3}\left(\frac{2(a-c)(2-\beta)}{(4-\gamma)(8-4 \gamma-\beta \gamma)}\right)^{2}$ \\
$\begin{array}{c}\text { One firm } \\
\text { innovates }\end{array}$ & $\pi_{i v}^{d}=2(3-\gamma)\left(\frac{(a-c)(2-\beta)(3-2 \gamma)\left(36-42 \gamma+3 \beta \gamma+10 \gamma^{2}-2 \beta \gamma^{2}\right)}{3\left(6-6 \gamma+\gamma^{2}\right)\left(72-72 \gamma+16 \gamma^{2}-\beta^{2} \gamma^{2}\right)}\right)^{2}-I$ \\
$\begin{array}{c}\text { Both firms } \\
\text { innovate }\end{array}$ & $\pi_{n v}^{d}=(3-2 \gamma)\left(\frac{(a-c)(2-\beta)(3-\gamma)\left(36-48 \gamma+6 \beta \gamma+16 \gamma^{2}-5 \beta \gamma^{2}\right)}{3\left(6-6 \gamma+\gamma^{2}\right)\left(72-72 \gamma+16 \gamma^{2}-\beta^{2} \gamma^{2}\right)}\right)^{2}$ \\
\hline
\end{tabular}

\section{(B.1d) Proof of Lemma 2}

Under decentralised union with no market expansion effect, we use the profit levels of firm 1 and firm 2 stated in (B.1c) to derive the following equilibrium conditions:

$(\mathrm{RD}, \mathrm{RD})$, i.e., both firms innovating is an equilibrium when

$$
\begin{aligned}
I<I_{l}^{d}=(2-\gamma)^{3}\left(\frac{2(a-c)(2-\beta)}{(4-\gamma)(8-4 \gamma-\beta \gamma)}\right)^{2}-(3-2 \gamma)\left(\frac{(a-c)(2-\beta)(3-\gamma)\left(36-48 \gamma+6 \beta \gamma+16 \gamma^{2}-5 \beta \gamma^{2}\right)}{3\left(6-6 \gamma+\gamma^{2}\right)\left(72-72 \gamma+16 \gamma^{2}-\beta^{2} \gamma^{2}\right)}\right)^{2} \\
=(2-\gamma)^{3}\left(\frac{2(a-c)(2-\beta)}{(4-\gamma)(8-4 \gamma-\beta \gamma)}\right)^{2}-(3-2 \gamma)\left(\frac{(a-c)(2-\beta)(3-\gamma)\left(36-48 \gamma+6 \beta \gamma+16 \gamma^{2}-5 \beta \gamma^{2}\right)}{3\left(6-6 \gamma+\gamma^{2}\right)\left(72-72 \gamma+16 \gamma^{2}-\beta^{2} \gamma^{2}\right)}\right)^{2}
\end{aligned}
$$

(No RD,No RD), i.e., neither firm innovating is an equilibrium when

$$
\begin{aligned}
& I>I_{h}^{d}=2(3-\gamma)\left(\frac{(a-c)(2-\beta)(3-2 \gamma)\left(36-42 \gamma+3 \beta \gamma+10 \gamma^{2}-2 \beta \gamma^{2}\right)}{3\left(6-6 \gamma+\gamma^{2}\right)\left(72-72 \gamma+16 \gamma^{2}-\beta^{2} \gamma^{2}\right)}\right)^{2}-(2-\gamma)^{3}\left(\frac{2(a-c)(2-\beta)}{(4-\gamma)(8-4 \gamma-\beta \gamma)}\right)^{2} \\
& \quad=2(3-\gamma)\left(\frac{(a-c)(2-\beta)(3-2 \gamma)\left(36-42 \gamma+3 \beta \gamma+10 \gamma^{2}-2 \beta \gamma^{2}\right)}{3\left(6-6 \gamma+\gamma^{2}\right)\left(72-72 \gamma+16 \gamma^{2}-\beta^{2} \gamma^{2}\right)}\right)^{2}-(2-\gamma)^{3}\left(\frac{2(a-c)(2-\beta)}{(4-\gamma)(8-4 \gamma-\beta \gamma)}\right)^{2} \\
& (\mathrm{RD}, \text { No RD) or (No RD,RD), i.e. either firm innovating is an equilibrium }
\end{aligned}
$$
when

$$
I_{l}^{d}<I<I_{h}^{d} \text { where, } I_{h}^{d}-I_{l}^{d}>0 \text { as shown in Figure } 3 .
$$




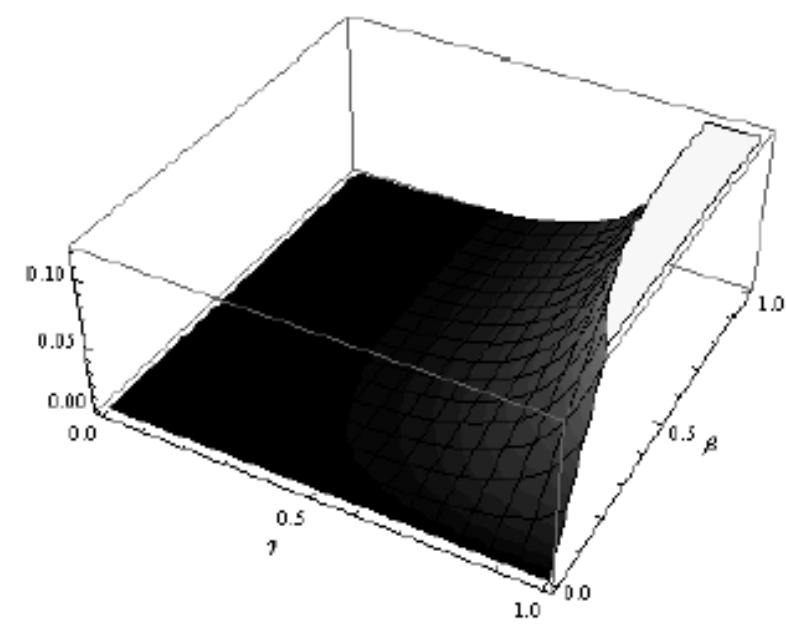

Figure 3

\section{(B.1e) Proof of Proposition 2}

Note

$$
\begin{aligned}
\frac{\partial I_{l}^{d}}{\partial \beta}= & \frac{1}{9}(2-\beta)^{2}\left(\frac{72 \gamma(2-\gamma)^{3}}{(4-\gamma)^{2}(8-4 \gamma-\beta \gamma)^{3}}\right. \\
& -\frac{4 \beta \gamma^{2}(3-\gamma)^{2}(3-2 \gamma)\left(36-48 \gamma+6 \beta \gamma+16 \gamma^{2}-5 \beta \gamma^{2}\right)^{2}}{\left(6-6 \gamma+\gamma^{2}\right)^{2}\left(72-72 \gamma+16 \gamma^{2}+\beta^{2} \gamma^{2}\right)^{3}} \\
& \left.-\frac{2 \gamma(3-\gamma)^{2}(3-2 \gamma)(6-5 \gamma)\left(36-48 \gamma+6 \beta \gamma+16 \gamma^{2}-5 \beta \gamma^{2}\right)}{\left(6-6 \gamma+\gamma^{2}\right)^{2}\left(72-72 \gamma+16 \gamma^{2}+\beta^{2} \gamma^{2}\right)^{2}}\right) \\
& -\frac{2}{9}(2-\beta)\left(\frac{36(2-\gamma)^{3}}{(4-\gamma)^{2}(8-4 \gamma-\beta \gamma)^{2}}-\frac{(3-\gamma)^{2}(3-2 \gamma)\left(36-48 \gamma+6 \beta \gamma+16 \gamma^{2}-5 \beta \gamma^{2}\right)}{\left(6-6 \gamma+\gamma^{2}\right)^{2}\left(72-72 \gamma+16 \gamma^{2}+\beta^{2} \gamma^{2}\right)^{2}}\right)
\end{aligned}
$$

and

$$
\begin{aligned}
\frac{\partial I_{h}^{d}}{\partial \beta}= & \frac{2}{9}\left(\frac{4 \beta \gamma^{2}(3-2 \gamma)^{2}(3-\gamma)\left(36-42 \gamma+3 \beta \gamma+10 \gamma^{2}-2 \beta \gamma^{2}\right)^{2}}{\left(6-6 \gamma+\gamma^{2}\right)^{2}\left(72-72 \gamma+16 \gamma^{2}-\beta^{2} \gamma^{2}\right)^{3}}\right. \\
& \left.+\frac{2 \gamma(3-2 \gamma)^{3}(3-\gamma)\left(36-42 \gamma+3 \beta \gamma+10 \gamma^{2}-2 \beta \gamma^{2}\right)}{\left(6-6 \gamma+\gamma^{2}\right)^{2}\left(72-72 \gamma+16 \gamma^{2}-\beta^{2} \gamma^{2}\right)^{2}}-\frac{36 \gamma(2-\gamma)^{3}}{(4-\gamma)^{2}(8-4 \gamma-\beta \gamma)^{3}}\right)
\end{aligned}
$$

Plotting the above expressions for $\gamma \in(0,1)$ and $\beta \in(0,1)$ in Figure 4 completes the proof. 


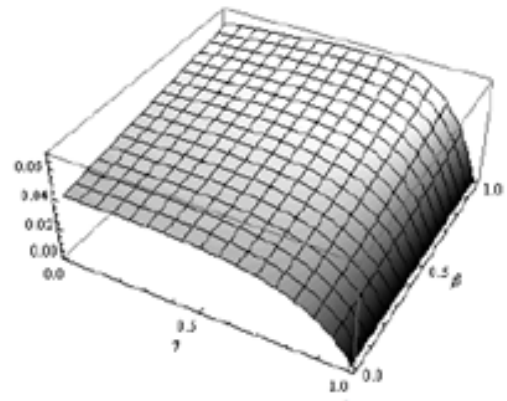

Figure 4a: $\frac{\partial I^{4}}{\partial f}>0$

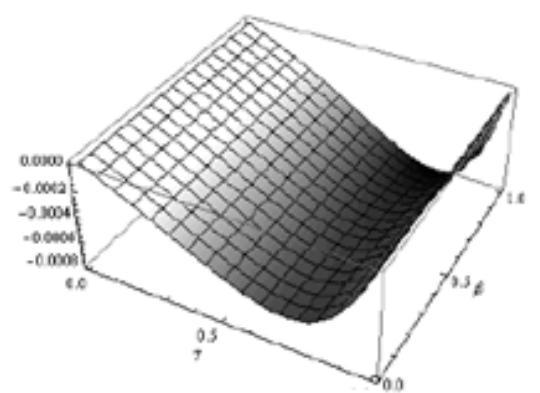

Figure 4b: $\frac{\partial I_{t}^{t}}{\partial t}<0$

Figure 4

(B.2) The case of full market expansion effect

(B.2a) The equilibrium wage rates:

\begin{tabular}{c|c} 
& Wage rates \\
\hline $\begin{array}{c}\text { Neither firm } \\
\text { innovates }\end{array}$ & $\widehat{w}_{1}^{d}=\widehat{w}_{2}^{d}=\frac{a \beta(2-\gamma)+2 c(2-\beta)}{4-\beta \gamma}$ \\
$\begin{array}{c}\text { One firm } \\
\text { innovates }\end{array}$ & $w_{i v}=\frac{a \beta\left(4+2 \gamma+\beta \gamma-2 \gamma^{2}\right)+c(2-\beta)(1+\gamma)(4+\beta \gamma)}{8+8 \gamma-\beta^{2}{ }^{2}}$ \\
& $w_{n v}=\frac{a \beta\left(4+2 \beta \gamma-\beta \gamma^{2}\right)+2 c(2-\beta)(2+2 \gamma+\beta \gamma)}{8+8 \gamma-\beta^{2} \gamma^{2}}$ \\
$\begin{array}{c}\text { Both firms } \\
\text { innovate }\end{array}$ & $\bar{w}_{1}^{d}=\bar{w}_{2}^{d}=\frac{a \beta+c(2-\beta)(1+\gamma)}{2+2 \gamma-\beta \gamma}$ \\
\hline
\end{tabular}

(B.2b) Proof of Lemma 3

$$
\begin{aligned}
\bar{w}_{k}^{d}-\widehat{w}_{k}^{d} & =-\frac{\beta \gamma(a-c)(2-\beta)(1-\gamma)}{(4-\beta \gamma)(2+2 \gamma-\beta \gamma)}<0 \\
w_{i v}-\widehat{w}_{k}^{d} & =-\frac{\beta^{2} \gamma^{2}(a-c)(2-\beta)(1-\gamma)}{(4-\beta \gamma)\left(8+8 \gamma-\beta^{2} \gamma^{2}\right)}<0
\end{aligned}
$$

Subtracting (B.2b.2) from (B.2b.1) yields

$$
\frac{2 \beta \gamma(a-c)(2-\beta)(1+\gamma)(1-\gamma)}{(2+2 \gamma-\beta \gamma)\left(8+8 \gamma-\beta^{2} \gamma^{2}\right)}>0
$$




\section{(B.2c) Firms' pay-off table}

\begin{tabular}{c|c} 
& Equilibrium profit levels \\
\hline $\begin{array}{c}\text { Neither firm } \\
\text { innovates }\end{array}$ & $\widehat{\pi}_{1}^{d}=\widehat{\pi}_{2}^{d}=\left(\frac{2(a-c)(2-\beta)}{(2+\gamma)(4-\beta \gamma)}\right)^{2}$ \\
$\begin{array}{c}\text { One firm } \\
\text { innovates }\end{array}$ & $\pi_{i v}^{d}=2(1+\gamma)\left(\frac{(a-c)(2-\beta)\left(4+2 \gamma+\beta \gamma-2 \gamma^{2}\right)}{\left(2+2 \gamma-\gamma^{2}\right)\left(8+8 \gamma-\beta^{2} \gamma^{2}\right)}\right)^{2}-I$ \\
$\begin{array}{c}\text { Both firms } \\
\text { innovate }\end{array}$ & $\pi_{n v}^{d}=\left(\frac{(a-c)(2-\beta)(1+\gamma)\left(4+2 \beta \gamma-\beta \gamma^{2}\right)}{\left(2+2 \gamma-\gamma^{2}\right)\left(8+8 \gamma-\beta^{2} \gamma^{2}\right)}\right)^{2}$ \\
\hline
\end{tabular}

\section{(B.2d) Proof of Lemma 4}

Under decentralised union case with market expansion effect, we use the profit levels of firm 1 and firm 2 stated in (B.2c) to derive the following equilibrium conditions:

$(\mathrm{RD}, \mathrm{RD})$, i.e., both firms innovating is an equilibrium when

$$
\begin{aligned}
I< & I_{l}^{d}=(2-\gamma)^{3}\left(\frac{2(a-c)(2-\beta)}{(4-\gamma)(8-4 \gamma-\beta \gamma)}\right)^{2}-\left(\frac{(a-c)(2-\beta)(1+\gamma)\left(4+2 \beta \gamma-\beta \gamma^{2}\right)}{\left(2+2 \gamma-\gamma^{2}\right)\left(8+8 \gamma-\beta^{2} \gamma^{2}\right)}\right)^{2} \\
& =\frac{1}{2}(a-c)^{2}(2-\beta)^{2}(1+\gamma)^{2}\left(\frac{1+\gamma}{(1+2 \gamma)^{2}(2+2 \gamma-\beta \gamma)^{2}}-\frac{2\left(4+2 \beta \gamma-\beta \gamma^{2}\right)^{2}}{\left(2+2 \gamma-\gamma^{2}\right)^{2}\left(8+8 \gamma-\beta^{2} \gamma^{2}\right)^{2}}\right)
\end{aligned}
$$

(No RD,No RD), i.e., neither firm innovating is an equilibrium when

$$
\begin{aligned}
I>I_{h}^{d} & =2(1+\gamma)\left(\frac{(a-c)(2-\beta)\left(4+2 \gamma+\beta \gamma-2 \gamma^{2}\right)}{\left(2+2 \gamma-\gamma^{2}\right)\left(8+8 \gamma-\beta^{2} \gamma^{2}\right)}\right)^{2}-\left(\frac{2(a-c)(2-\beta)}{(2+\gamma)(4-\beta \gamma)}\right)^{2} \\
& =2(a-c)^{2}(2-\beta)^{2}\left(\frac{(1+\gamma)\left(4+2 \gamma+\beta \gamma-2 \gamma^{2}\right)^{2}}{\left(2+2 \gamma-\gamma^{2}\right)^{2}\left(8+8 \gamma-\beta^{2} \gamma^{2}\right)^{2}}-\frac{2}{(2+\gamma)^{2}(4-\beta \gamma)^{2}}\right)
\end{aligned}
$$

(RD,No RD) or (No RD,RD), i.e., either firm innovating is an equilibrium when

$I_{l}^{d}<I<I_{h}^{d}$ where, $I_{h}^{d}-I_{l}^{d}>0$ as shown in Figure $\mathbf{5}$. 


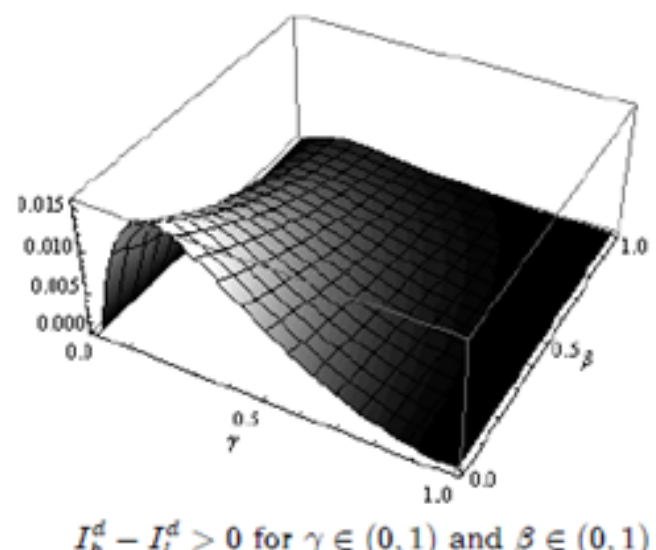

Figure 5

\section{(B.2e) Proof of Proposition 2}

Note, $\frac{\partial I_{l}^{d}}{\partial \beta}$

$$
\begin{aligned}
= & \frac{1}{2}(2-\beta)^{2}(1+\gamma)^{2}\left(\frac{2 \gamma(1+\gamma)}{(1+2 \gamma)^{2}(2+2 \gamma-\beta \gamma)^{3}}-\frac{8 \beta \gamma^{2}\left(4+2 \beta \gamma-\beta \gamma^{2}\right)^{2}}{\left(2+2 \gamma-\gamma^{2}\right)^{2}\left(8+8 \gamma-\beta^{2} \gamma^{2}\right)^{3}}-\frac{4 \gamma(2-\gamma)\left(4+2 \beta \gamma-\beta \gamma^{2}\right)}{\left(2+2 \gamma-\gamma^{2}\right)^{2}\left(8+8 \gamma-\beta^{2} \gamma^{2}\right)^{2}}\right) \\
& -(2-\beta)(1+\gamma)^{2}\left(\frac{1+\gamma}{(1+2 \gamma)^{2}(2+2 \gamma-\beta \gamma)^{2}}-\frac{2\left(4+2 \beta \gamma-\beta \gamma^{2}\right)^{2}}{\left(2+2 \gamma-\gamma^{2}\right)^{2}\left(8+8 \gamma-\beta^{2} \gamma^{2}\right)^{2}}\right) .
\end{aligned}
$$

And, $\frac{\partial I_{h}^{d}}{\partial \beta}$

$=2(2-\beta)^{2}\left(\frac{4 \beta \gamma^{2}(1+\gamma)\left(4+2 \gamma+\beta \gamma-2 \gamma^{2}\right)^{2}}{\left(2+2 \gamma-\gamma^{2}\right)^{2}\left(8+8 \gamma-\beta^{2} \gamma^{2}\right)^{3}}+\frac{2 \gamma(1+\gamma)\left(4+2 \gamma+\beta \gamma-2 \gamma^{2}\right)}{\left(2+2 \gamma-\gamma^{2}\right)^{2}\left(8+8 \gamma-\beta^{2} \gamma^{2}\right)^{2}}-\frac{4 \gamma}{(2+\gamma)^{2}(4-\beta \gamma)^{3}}\right)$ $-4(2-\beta)\left(\frac{(1+\gamma)\left(4+2 \gamma+\beta \gamma-2 \gamma^{2}\right)^{2}}{\left(2+2 \gamma-\gamma^{2}\right)^{2}\left(8+8 \gamma-\beta^{2} \gamma^{2}\right)^{2}}-\frac{2}{(2+\gamma)^{2}(4-\beta \gamma)^{2}}\right)$.

Plotting the above expressions for $\gamma \in(0,1)$ and $\beta \in(0,1)$ in Figure 6 completes the proof: 


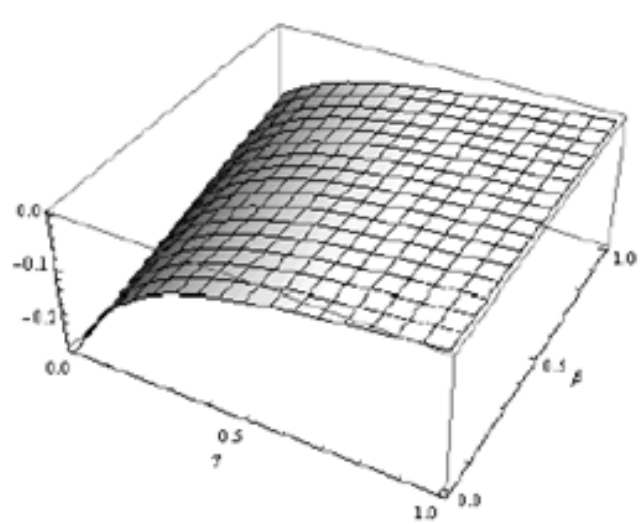

Figure 6a: $\frac{\partial I_{j}^{d}}{\partial \delta}<0$

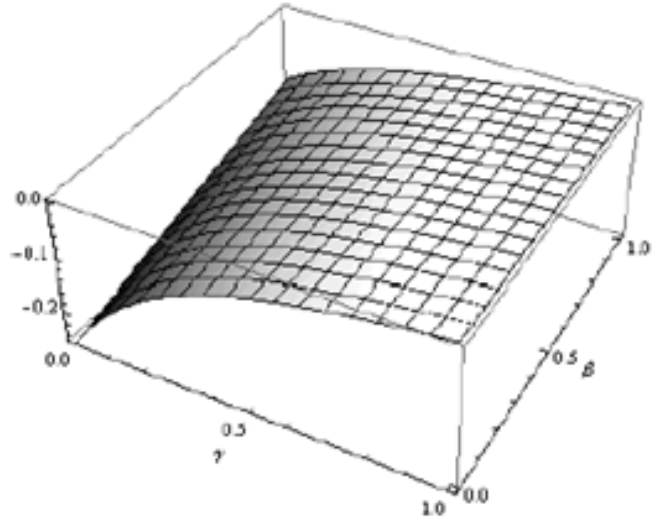

Figure $6 \mathrm{~b}$ : $\frac{\partial I_{\mathrm{b}}^{d}}{\partial \mathrm{B}}<0$

Figure 6

\section{Appendix C: The case of Centralised Union}

(C.1) The case of no market expansion effect

(C.1a) Firm's pay-off table

\begin{tabular}{c|c} 
& No market expansion effect \\
\hline $\begin{array}{c}\text { Neither firm } \\
\text { Innovates }\end{array}$ & $\widehat{\pi}_{1}^{c}=\widehat{\pi}_{2}^{c}=\left(\frac{2-\gamma}{4}\right)\left(\frac{(a-c)(2-\beta)}{4-\gamma}\right)^{2}$ \\
$\begin{array}{c}\text { One firm } \\
\text { innovates }\end{array}$ & $\pi_{i v}^{c}=\left(\frac{3-\gamma}{72}\right)\left(\frac{(a-c)(2-\beta)(6-5 \gamma)}{6-6 \gamma+\gamma^{2}}\right)^{2}-I$ \\
& $\pi_{n v}^{c}=(3-2 \gamma)^{3}\left(\frac{(a-c)(2-\beta)}{6\left(6-6 \gamma+\gamma^{2}\right)}\right)^{2}$ \\
$\begin{array}{c}\text { Both firms } \\
\text { innovate }\end{array}$ & $\bar{\pi}_{1}^{c}=\bar{\pi}_{2}^{c}=\left(\frac{2-\gamma}{4}\right)\left(\frac{(a-c)(2-\beta)}{4-\gamma}\right)^{2}-I$ \\
\hline
\end{tabular}

\section{(C.1b) Proof of Lemma 5}

Under a centralised union with no market expansion effect, we use the profit levels of firm 1 and firm 2 stated in (C.1a) to derive the following equilibrium conditions:

$(\mathrm{RD}, \mathrm{RD})$, i.e. both firms innovating is an equilibrium when 


$$
\begin{aligned}
I<I_{l}^{c} & =\left(\frac{2-\gamma}{4}\right)\left(\frac{(a-c)(2-\beta)}{4-\gamma}\right)^{2}-(3-2 \gamma)^{3}\left(\frac{(a-c)(2-\beta)}{6\left(6-6 \gamma+\gamma^{2}\right)}\right)^{2} \\
& =\frac{(a-c)^{2}(2-\beta)^{2}(1-\gamma)\left(216-324 \gamma+153 \gamma^{2}-25 \gamma^{3}+\gamma^{4}\right)}{36(4-\gamma)^{2}\left(6-6 \gamma+\gamma^{2}\right)^{2}}
\end{aligned}
$$

(No RD,No RD), i.e., neither firm innovating is an equilibrium when

$$
\begin{aligned}
I>I_{h}^{c} & =\left(\frac{3-\gamma}{72}\right)\left(\frac{(a-c)(2-\beta)(6-5 \gamma)}{6-6 \gamma+\gamma^{2}}\right)^{2}-\left(\frac{2-\gamma}{4}\right)\left(\frac{(a-c)(2-\beta)}{4-\gamma}\right)^{2} \\
& =\frac{(a-c)^{2}(2-\beta)^{2}(1-\gamma)\left(432-648 \gamma+324 \gamma^{2}-76 \gamma^{3}+7 \gamma^{4}\right)}{72(4-\gamma)^{2}\left(6-6 \gamma+\gamma^{2}\right)^{2}}
\end{aligned}
$$

(RD,No RD) or (No RD, RD), i.e. either firm innovating is an equilibrium when $I_{l}^{c}<I<I_{h}^{c}$ where, $I_{h}^{c}-I_{l}^{c}=\frac{\gamma^{2}(a-c)^{2}(2-\beta)^{2}(1-\gamma)\left(18-26 \gamma+5 \gamma^{2}\right)}{72(4-\gamma)^{2}\left(6-6 \gamma+\gamma^{2}\right)^{2}}>0$.

\section{(C.1c) Proof of Proposition 3}

$$
\begin{aligned}
\frac{\partial I_{l}^{c}}{\partial \beta} & =-\frac{(a-c)^{2}(2-\beta)(1-\gamma)\left(216-324 \gamma+153 \gamma^{2}-25 \gamma^{3}+\gamma^{4}\right)}{18(4-\gamma)^{2}\left(6-6 \gamma+\gamma^{2}\right)^{2}}<0 \\
\frac{\partial I_{h}^{c}}{\partial \beta} & =-\frac{(a-c)^{2}(2-\beta)(1-\gamma)\left(432-648 \gamma+324 \gamma^{2}-76 \gamma^{3}+7 \gamma^{4}\right)}{36(4-\gamma)^{2}\left(6-6 \gamma+\gamma^{2}\right)^{2}}<0
\end{aligned}
$$

(C.2) The case of full market-expansion effect

(C.2a) Firm's pay-off table

\begin{tabular}{c|c} 
Neither firm & Full market expansion effect \\
\hline $\begin{array}{c}\text { Innovates } \\
\text { One firm }\end{array}$ & $\widehat{\pi}_{1}^{c}=\widehat{\pi}_{2}^{c}=\left(\frac{(a-c)(2-\beta)}{2(2+\gamma)}\right)^{2}$ \\
innovates & $\pi_{i v}^{c}=\left(\frac{1+\gamma}{8}\right)\left(\frac{(a-c)(2-\beta)(2-\gamma)}{2+2 \gamma-\gamma^{2}}\right)^{2}-I$ \\
$\pi_{n v}^{c}=\frac{1}{4}\left(\frac{(a-c)(2-\beta)}{2+2 \gamma-\gamma^{2}}\right)^{2}$ \\
$\begin{array}{c}\text { Both firms } \\
\text { innovate }\end{array}$ & $\bar{\pi}_{1}^{c}=\bar{\pi}_{2}^{c}=\left(\frac{1+\gamma}{8}\right)\left(\frac{(a-c)(2-\beta)}{1+2 \gamma}\right)^{2}-I$ \\
\hline
\end{tabular}




\section{(C.2b) Proof of Lemma 5}

Under a centralised union with market expansion effect, we use the profit levels of firm 1 and firm 2 stated in (C.2a) to derive the following equilibrium conditions:

$(\mathrm{RD}, \mathrm{RD})$, i.e., both firms innovating is an equilibrium when

$$
\begin{aligned}
I<I_{l}^{c} & =\left(\frac{1+\gamma}{8}\right)\left(\frac{(a-c)(2-\beta)}{1+2 \gamma}\right)^{2}-\frac{1}{4}\left(\frac{(a-c)(2-\beta)}{2+2 \gamma-\gamma^{2}}\right)^{2} \\
& =\frac{(a-c)^{2}(2-\beta)^{2}(1-\gamma)\left(2+6 \gamma+6 \gamma^{2}+2 \gamma^{3}-\gamma^{4}\right)}{8(1+2 \gamma)^{2}\left(2+2 \gamma-\gamma^{2}\right)^{2}}
\end{aligned}
$$

(No RD,No RD), i.e., neither firm innovating is an equilibrium when

$$
\begin{aligned}
I>I_{h}^{c} & =\left(\frac{1+\gamma}{8}\right)\left(\frac{(a-c)(2-\beta)(2-\gamma)}{2+2 \gamma-\gamma^{2}}\right)^{2}-\left(\frac{(a-c)(2-\beta)}{2(2+\gamma)}\right)^{2} \\
& =\frac{(a-c)^{2}(2-\beta)^{2}(1-\gamma)\left(8+8 \gamma-\gamma^{4}\right)}{8(2+\gamma)^{2}\left(2+2 \gamma-\gamma^{2}\right)^{2}}
\end{aligned}
$$

( $\mathrm{RD}, \mathrm{No}_{\mathrm{RD}}$ ) or (No RD,RD), i.e., either firm innovating is an equilibrium when

$$
I_{l}^{c}<I<I_{h}^{c} \text { where, } I_{h}^{c}-I_{l}^{c}=\frac{\gamma(a-c)^{2}(2-\beta)^{2}(1-\gamma)^{2}(1+\gamma)\left(8+14 \gamma+2 \gamma^{2}+3 \gamma^{3}\right)}{8(2+\gamma)^{2}(1+2 \gamma)^{2}\left(2+2 \gamma-\gamma^{2}\right)^{2}}>0 .
$$

\section{(C.2c) Proof of Proposition 3}

$$
\begin{aligned}
\frac{\partial I_{l}^{c}}{\partial \beta} & =-\frac{(a-c)^{2}(2-\beta)(1-\gamma)\left(2+6 \gamma+6 \gamma^{2}+2 \gamma^{3}-\gamma^{4}\right)}{4(1+2 \gamma)^{2}\left(2+2 \gamma-\gamma^{2}\right)^{2}}<0 \\
\frac{\partial I_{h}^{c}}{\partial \beta} & =-\frac{(a-c)^{2}(2-\beta)(1-\gamma)\left(8+8 \gamma-\gamma^{4}\right)}{4(2+\gamma)^{2}\left(2+2 \gamma-\gamma^{2}\right)^{2}}<0
\end{aligned}
$$




\section{References}

[1] Addison, J. T. and J. Wagner, 1994, 'UK unionism and innovative activity: some cautionary remarks on the basis of a simple cross-country test', British Journal of Industrial Relations, 32: 83-98.

[2] Bassanini, A. and E. Ernst, 2002, 'Labour market institutions, product market regulation, and innovation: cross country evidence', OECD Economics Department Working Paper, 316, Paris.

[3] Bronas, S. G. and D. R. Deere, 1993, 'Unionisation, incomplete contracting, and capital investment', Journal of Business, 66: 117-32.

[4] Bughin, J and S. Vannini, 1995, 'Strategic direct investment under unionized oligopoly', International Journal of Industrial Organization, 13: 127-45.

[5] Calabuig, V. and M. Gonzalez-Maestre, 2002, 'Union structure and incentives for innovation', European Journal of Political Economy, 18, 177-92.

[6] Calmfors, L. and J. Drifill, 1988, 'Centralisation and wage bargaining', Economic Policy, 6: 13-61.

[7] Davidson, C., 1988, 'Multiunit Bargaining in oligopolistic industries', Journal of Labor Economics 6, 397-422.

[8] Degraba, P., 1990, 'Input market price discrimination and the choice of technology', American Economic Review, 80: 1246-53.

[9] Dhillon, A. and E. Petrakis, 2002, 'A generalized wage rigidity result', International Journal of Industrial Organization, 20: 285-311.

[10] Dobson, P. W., 1994, 'Multifirm unions and the incentive to adopt pattern bargaining in oligopoly', European Economic Review, 38: 87-100.

[11] Flanagan, R. J., 1999, 'Macroeconomic performance and collective bargaining: an international perspective', Journal of Economic Literature, 37: 1150-75.

[12] Freeman, R. and J. Medoff, 1984, What do unions do?, Basic Books, New York.

[13] Gallini, N. T., 1992, 'Patent policy and costly imitation', RAND Journal of Economics, 23: 52-63.

[14] Grout, P. A., 1984, 'Investment and wages in the absence of binding contracts: a Nash bargaining approach', Econometrica, 52: 449-60.

[15] Haucap, J., U. Pauly and C. Wey, 2001, 'Collective wage setting when wages generally are generally binding: an antitrust perspective', International Review of Law and Economics, 21: 287-307. 
[16] Haucap, J. and C. Wey, 2004, 'Unionisation structures and innovation incentives', Economic Journal 114: C149-65.

[17] Hirsch, B. J., 1992, 'Firm investment behavior and collective bargaining strategy', Industrial Relations, 31: 95-121.

[18] Horn, H. and A. Wolinsky, 1988, 'Bilateral monopolies and incentive for merger', Rand Journal of Economics 19, 408-19.

[19] Imai, K., 1992, 'The Japanese pattern of innovation and its evolution', in N. Rosenberg, R. Laudan and D. Mowery (Eds.), Technology and the wealth of nations, Stanford University Press, Stanford.

[20] Kamien, M., 1992, 'Patent licensing', in R. J. Aumann and S. Hart (Eds.), Handbook of game theory, ch. 11, Elsevier.

[21] Katz, H. C., 1993, 'The decentralization of collective bargaining: a literature review and comparative analysis', Industrial and Labor Relations Review, 47: 3-22.

[22] Lambertini, L. and A. Mantovani, 2009, 'Process and product innovation by a multiproduct monopolist: a dynamic approach', International Journal of Industrial Organization, 27: 508-18.

[23] Lambertini, L. and A. Mantovani, 2010, 'Process and product innovation: a differential game approach to product life cycle', International Journal of Economic Theory, 6: 227-52.

[24] Layard, R., S. Nickell and R. Jackman, 1991, Unemployment, macroeconomic performance and the labour market, Oxford University Press, Oxford.

[25] Lin, P. and K. Saggi, 2002, 'Product differentiation, process R\&D, and the nature of market competition', European Economic Review, 46: 201-11.

[26] López, M. C. and R. A. Naylor, 2004, 'The Cournot-Bertrand profit differential: a reversal result in a differentiated duopoly with wage bargaining', European Economic Review, 48: 681-96.

[27] Manasakis, C. and E. Petrakis, 2009, 'Union structure and firms' incentives for cooperative R\&D investments', Canadian Journal of Economics, 42: 665-93.

[28] Mansfield, E., 1988, 'Industrial R\&D in Japan and the United States: a comparative study', American Economic Review, 78: 223-28.

[29] Menezes-Filho, N. and J. Van Reenen, 2003, 'Unions and innovation: a survey of the theory and empirical evidence', CEPR Discussion Paper, No. 3792. 
[30] Menezes-Filho, N., D. Ulph and J. Van Reenen, 1998, 'The determination of R\&D: empirical evidence on the rule of unions', European economic Review, 42: 919-30.

[31] Moene, K. O. and M. Wallerstein, 1997, 'Pay inequality', Journal of Labour Economics, 15: 403-30.

[32] Mukherjee, A., 2007, 'Irrelevance of productivity difference: a case with labor union', Economics Bulletin, 10: 1-8.

[33] Mukherjee, A. and E. Pennings, 2004, 'Imitation, patent protection and welfare', Oxford Economic Papers, 56: 715-33.

[34] Mukherjee, A. and E. Pennings, 2011, 'Unionization structure, licensing and innovation', International Journal of Industrial Organization, 29: $232-41$.

[35] Mukherjee, A. and A. Ray, 2007, 'Patents, Imitation and Welfare', Economics of Innovation and New Technology,16: 227-36.

[36] Mukherjee, A. and U. B. Sinha, 2013, 'Patent Protection, Southern Innovation and Welfare in a North-South Trade Model', Economica, 80: 248-73.

[37] Nickell, S., 1997, 'Unemployment and labour market rigidities: Europe versus North America', Journal of Economic Perspectives, 11: 55-74.

[38] OECD, 1996, The OECD jobs study: implementing the strategy, OECD, Paris.

[39] OECD, 2004, Trade and migration: building bridges for global labour mobility, OECD, Paris.

[40] Pavitt, K., M. Robson and J. Townsend (1987), "The Size Distribution of Innovating Firms in the UK: 1945-1983", Journal of Industrial Economics, 35, 297-316.

[41] Roy Chowdhury, P., 2005, 'Patents and R\&D: the tournament effect', Economics Letters, 89: 120-26.

[42] Siebert, H., 1997, 'Labour market rigidities: at the root of unemployment in Europe', Journal of Economic Perspectives, 11: 37-54.

[43] Tauman, Y. and Y. Weiss, 1987, 'Labor unions and the adoption of new technology', Journal of Labor Economics, 5: 477-501.

[44] Ulph, A. M., 1989, 'The incentives to make commitments in wage bargains', Review of Economic Studies, 56: 449-66.

[45] Ulph, A. M. and D. T. Ulph, 1989, 'Labour markets and innovation', Journal of Japanese and International Economics, 3: 403-23.

[46] Ulph, A. M. and D. T. Ulph, 1994, 'Labour markets and innovation: expost bargaining', European Economic Review, 38: 195-210. 
[47] Ulph, A. M. and D. T. Ulph, 1998, 'Labour markets, bargaining and innovation', European Economic Review, 42: 931-39.

[48] Ulph, A. M. and D. T. Ulph, 2001, 'Strategic innovation with complete and incomplete labour market contracts', Scandinavian Journal of Economics, 103: 265-82.

[49] Van der Ploeg, F., 1987, 'Trade unions, investment, and employment', European Economic Review, 31: 1465-92.

[50] Vannini, S. and J. Bughin, 2000, 'To be (unionized) or not to be? a case for cost-raising strategies under Cournot oligopoly', European Economic Review, 44: 1763-81.

[51] Walsworth, S., 2010, 'What do unions do to innovation? An empirical examination of the Canadian private sector', Relations industrielles / Industrial Relations, 65: 543-61. 